Article

\title{
New Roles for Two-Component System Response Regulators of Salmonella enterica Serovar Typhi during Host Cell Interactions
}

\author{
Claudie Murret-Labarthe, Maud Kerhoas, Karine Dufresne and France Daigle *(D) \\ Département de microbiologie, infectiologie, immunologie, Université de Montréal, \\ Montréal, QC H3T 1J4, Canada; c.m.labarthe@gmail.com (C.M.-L.); maud1693@hotmail.com (M.K.); \\ karine.dufresne@umontreal.ca (K.D.) \\ * Correspondence: france.daigle@umontreal.ca
}

Received: 9 April 2020; Accepted: 9 May 2020; Published: 13 May 2020

check for updates

\begin{abstract}
In order to survive external stresses, bacteria need to adapt quickly to changes in their environment. One adaptive mechanism is to coordinate and alter their gene expression by using two-component systems (TCS). TCS are composed of a sensor kinase that activates a transcriptional response regulator by phosphorylation. TCS are involved in motility, virulence, nutrient acquisition, and envelope stress in many bacteria. The pathogenic bacteria Salmonella enterica serovar Typhi (S. Typhi) possess $30 \mathrm{TCSs}$, is specific to humans, and causes typhoid fever. Here, we have individually deleted each of the 30 response regulators. We have determined their role during interaction with host cells (epithelial cells and macrophages). Deletion of most of the systems (24 out of 30) resulted in a significant change during infection. We have identified 32 new phenotypes associated with TCS of S. Typhi. Some previously known phenotypes associated with TCSs in Salmonella were also confirmed. We have also uncovered phenotypic divergence between Salmonella serovars, as distinct phenotypes between $S$. Typhi and $S$. Typhimurium were identified for $c p x R$. This finding highlights the importance of specifically studying $S$. Typhi to understand its pathogenesis mechanisms and to develop strategies to potentially reduce typhoid infections.
\end{abstract}

Keywords: Salmonella Typhi; two-component system; cpxR

\section{Introduction}

Bacteria possess a variety of systems that enable them to respond to diverse signals received from the external environment. These signals are mainly detected by two-component systems (TCS) composed of a histidine sensor kinase (SK) and a response regulator (RR). Physical or chemical signals, such as changes in extracellular ion concentrations, $\mathrm{pH}$, oxygen, osmolarity, quorum sensing, and the presence of antibiotics are some of the signals detected by TCS. TCS are involved in adaptation to several conditions, notably stress conditions, host-pathogen interactions, symbiotic interactions, and intracellular signaling [1,2].

The SK partner of the TCS is located in the inner membrane and generally comprises two domains, a receiver and a transmitter domain that contains a kinase activity with a conserved histidine residue. Typically, the RR proteins are located in the cytoplasm and also comprise two domains, a receiver domain in the $\mathrm{N}$-terminal section of the protein containing a conserved aspartate residue and a response domain in the C-terminal of the protein. When a signal is detected by the SK, this results in autophoshorylation of the conserved histidine residue, an ATP-dependent process. The SK then activates the RR through transfer of its phosphorylated group to the conserved RR aspartate residue. 
Once activated, the RR initiates the adaptive transcriptional response, through activation or repression of genes that will adjust the bacterial lifestyle to the conditions encountered [3].

Salmonella enterica serovar Typhi (S. Typhi) is a human-specific bacterial pathogen and the etiologic agent of the typhoid fever. This disease is common in Africa and Southeast Asia and causes between 11.9 and 26.9 million cases and 128,000 to 216,500 deaths per year [4]. Infection with this pathogen occurs through the ingestion of contaminated food or water. Once ingested, Salmonella must first resist stomach acidity [5,6], then reach the small intestine, cross the mucosal barrier of the intestine, and gain access to intestinal epithelial cells. Bacteria can then invade epithelial cells using the type-three secretion system (T3SS) located on Salmonella pathogenicity island 1 (SPI-1) [7,8]. S. Typhi does not elicit a strong intestinal immune response or inflammation, mainly by producing the Vi capsule [9]. It crosses the intestinal barrier, infects macrophages, and survives within vacuoles by using a second T3SS located on SPI-2 [10,11]. S. Typhi then causes a systemic infection by disseminating to deeper tissues including spleen, liver, bone marrow, and gallbladder [12].

Currently, most of our knowledge concerning TCS was obtained from studies done in Escherichia coli or Salmonella enterica serovar Typhimurium. Thus far, only six TCS have been characterized in S. Typhi. Both the EnvZ-OmpR system and the Rcs system activate the expression of the Vi capsule $[13,14]$. The Rcs system also represses invasion proteins and flagellin [14-17]. The PhoPQ system regulates the $S$. Typhi-specific CdtB, ClyA, and TaiA toxins [18-20], is expressed in typhoid patients [21], and a phoPQ deletion was used in a live attenuated $S$. Typhi vaccine [22]. The SsrAB system had no role in survival in macrophages in S. Typhi [23]. The CpxAR system is involved in adhesion and invasion of human intestinal epithelial cells and is activated by osmolarity [24]. The QseCB system is activated by several signals, including neurotransmitters (epinephrine and norepinephrine) $[25,26]$, and invasion of epithelial cells increased in a qseB mutant of $S$. Typhi [27]. UhpBA regulates glucose-6-phosphate transport [28]. A comparative study of the transcriptional profile performed in $S$. Typhi indicates that UhpA was involved in the sulfur assimilation pathway [29]. Other TCS have not been studied in $S$. Typhi and some TCS have not been investigated in S. Typhimurium (CitAB, CreCB, DpiBA, TctED, and TorSR).

As some TCS play a role in S. Typhi infection, it is likely that other TCS may have a significant role in different stages of disease by this pathogen. To study the TCS of $S$. Typhi, we have deleted each of the genes encoding RR proteins, since it has been shown that some SK can also activate non-specific RR and complement defects of the specific corresponding SK mutant [30]. Non-polar deletions of genes encoding each RR protein were created by allelic exchange and we evaluated the ability of each mutant to adhere, invade, and replicate in human epithelial cells and to be phagocytosed and survive in human macrophages. This study represents a comprehensive characterization of all S. Typhi TCS and identifies a potential role for each of these systems in $S$. Typhi pathogenesis.

\section{Materials and Methods}

\subsection{Bacterial Strains and Growth Conditions}

S. Typhi strain ISP1820 was used throughout this study as the main wild-type strain [31]. Strains and plasmids used in this study are listed in Supplementary Tables S1 and S2, respectively. Bacteria were routinely grown overnight in Luria-Bertani (LB) broth, with agitation at $37^{\circ} \mathrm{C}$, unless indicated otherwise. Antibiotic or supplements were added at the following concentration: $34 \mu \mathrm{g} / \mathrm{mL}$ chloramphenicol and $50 \mu \mathrm{g} / \mathrm{mL}$ diaminopimelic acid, when required. Bacterial transformation was performed using the calcium/manganese-based method, as previously described [32].

\subsection{Chromosomal Deletion of TCS Regulatory Genes}

Thirty TCS were identified in the sequenced genome of $S$. Typhi strain CT18 [33] by searching for DNA binding protein and regulator. The non-polar deletion of all the response regulator (RR) encoding genes were obtained by allelic exchange, as described previously [34], using the overlap-extension 
PCR method [35]. Deletions were confirmed by PCR. The primers used for mutagenesis are listed in Supplementary Table S3.

\subsection{Interaction with Cultured Human Epithelial Intestinal Cells}

The INT-407 (ATCC CCL-6) cells were cultivated in Eagle minimal essential medium (EMEM) (Wisent, St-Bruno, QC, Canada) supplemented with 10\% heat-inactivated fetal bovine serum (FBS) (Wisent) and $25 \mathrm{mM} \mathrm{HEPES} \mathrm{(Wisent,} \mathrm{St-Bruno,} \mathrm{QC,} \mathrm{Canada).} \mathrm{The} \mathrm{gentamicin} \mathrm{protection} \mathrm{assay} \mathrm{described}$ previously was adapted to 96-well plates and performed at a multiplicity of infection (MOI) of 20 [34]. Bacteria were grown overnight in static condition (low aeration) in $\mathrm{LB}-\mathrm{NaCl}(300 \mathrm{mM})$ to induce SPI-1 and were added in triplicate. After $90 \mathrm{~min}$, infected cells were washed with phosphate-buffer saline (PBS) and fresh medium supplemented with $50 \mu \mathrm{g} / \mathrm{mL}$ gentamicin was added to kill the extracellular bacteria. Cells were lysed with PBS and $0.1 \%$ sodium deoxycholate (PBS-DOC) at 90 min (adhesion), $180 \mathrm{~min}$ (invasion), and $18 \mathrm{~h}$ (survival) post-infection. Serial dilutions were performed for enumeration of viable colony counts by colony-forming units $(\mathrm{CFU} / \mathrm{mL})$. The assay was performed at least three times in triplicate.

\subsection{Infection of Cultured Macrophages}

The THP-1 (ATCC TIB-202) cells were cultivated in RPMI 1640 (Wisent, St-Bruno, QC, Canada) supplemented with $10 \%$ heat-inactivated FBS (Wisent), $1 \mathrm{mM}$ sodium pyruvate (Wisent), and $1 \%$ MEM non-essential amino acids (Wisent, St-Bruno, QC, Canada). The human monocytes cells were differentiated into macrophages by addition of $10^{-7} \mathrm{M}$ phorbol 12-myristate 13 acetate (Sigma) for $48 \mathrm{~h}$ before the infection. Similarly, the RAW264.7 (ATCC TIB-71) murine macrophages were cultivated in Dulbecco's Modified Eagle's Medium (DMEM; Wisent, St-Bruno, QC, Canada). The method was adapted to 96-well plates and performed at a MOI of 10 [36]. To obtain a similar number of intracellular bacteria, a MOI of 10 was used for macrophages to compensate for the phagocytic activity. Briefly, following an overnight growth in LB broth, the strains were added in triplicate. After $30 \mathrm{~min}$, infected cells were washed with PBS, treated with gentamicin $(50 \mathrm{ug} / \mathrm{mL})$, and lysed with PBS-DOC $0.1 \%$ at $30 \mathrm{~min}$ (phagocytosis), and $18 \mathrm{~h}$ (survival) post-infection, then, serial dilutions were performed for enumeration of viable colony counts $(\mathrm{CFU} / \mathrm{mL})$. Each deletion was tested at least three times in triplicate.

\subsection{Motility Assays}

Motility assays were performed in a tube, containing the «Motility Test Medium» (BBL, BD, Mississauga, ON, Canada), in which a solution of $1 \%$ of triphenyltetrazolium chloride was added. These agar tubes were inoculated by stabbing the agar with an overnight culture of bacteria. The tubes were then incubated at $37^{\circ} \mathrm{C}$ for approximately $18 \mathrm{~h}$, to evaluate the motility of the mutants. For each deletion, this assay was performed at least three times. Motility assays on plates were performed as described previously [37].

\section{Results}

\subsection{Deletion and Characterization of $R R$ Mutants}

We have identified 30 RR genes in the genome of $S$. Typhi and an overview of their putative functions is summarized in Table 1. These TCS were all detected in the genome of the closely related serovar Typhimurium. However, these two serovars have a different host range, and cause distinct disease, suggesting that potential differences between these serovars may involve differences in gene regulation. All RR were deleted individually. Deletion of an internal fragment of each RR was achieved by allelic exchange in S. Typhi strain ISP1820. Each marker-less deletion was in frame, to avoid any polar effect. Mutants were characterized for their growth, susceptibility to aminoglycoside, and motility. All mutants had a similar growth curve in LB compared to the wild-type parent strain (data not 
shown). The arcA mutant produced smaller colonies on LB agar. The mutants were all sensitive to gentamicin and most mutants were motile as the wild-type (except for che $Y$, as expected, and ompR, which demonstrated a reduced swimming area, $85 \%$ of the wild-type, in motility medium).

Table 1. Two-component systems of Salmonella Typhi and their putative function.

\begin{tabular}{|c|c|c|}
\hline SK & RR & Function \\
\hline ArcB (STY3507) & ArcA (STY4947) & $\begin{array}{l}\text { Global aerobic respiration control; oxidative stress [38,39]; SPI-1 } \\
\text { activation [40]; motility [41]; defective in invasion and survival [42] }\end{array}$ \\
\hline BaeS (STY2343) & BaeR (STY2155) & $\begin{array}{l}\text { Envelope stress: (antimicrobial resistance (AMR) and metal } \\
\text { resistance) }[43,44]\end{array}$ \\
\hline CitA (STY0062) & CitB (STY0061) & Anaerobic citrate fermentation ${ }^{\mathrm{a}}[45]$ \\
\hline CheA (STY2130) & CheY (STY2125) & Chemotaxis; required for virulence in mice [46], and in invasion [47] \\
\hline CopS (STY1127) & CopR (STY1128) & Uncharacterized $^{\text {a }}$ \\
\hline CpxA (STY3813) & CpxR (STY3812) & $\begin{array}{l}\text { Membrane stress (AMR and metal resistance) }[48-52] \text {; SPI-1 } \\
\text { repression }[53,54] \text { and SPI-2 regulation [55]; virulence }[53,55,56]\end{array}$ \\
\hline CreC (STY4936) & CreB (STY4935) & Carbon source metabolism ${ }^{\mathrm{a}}[57]$ \\
\hline DcuS (STY4502) & DcuR (STY4501) & C4-dicarboxylates catabolism ${ }^{\text {a }}$ [57-59] \\
\hline DpiB (STY0674) & DpiA (STY0675) & SOS response ${ }^{a}[60]$ \\
\hline GlnL (STY3875) & GlnG (STY3876) & Nitrogen response $[61,62]$ \\
\hline HydH (STY3712) & HydG (STY3211) & Zinc transport ${ }^{\text {a }}[63]$ \\
\hline KdpD (STY0744) & KdpE (STY0743) & Potassium transport [64], C. elegans colonization [65] \\
\hline NarX (STY1286) & NarL (STY1285) & Nitrate responsive $[66,67]$ \\
\hline NarQ (STY2718) & NarP (STY2472) & Nitrate respiration [66] ${ }^{a}$; Involved in virulence [68] \\
\hline EnvZ (STY4295) & OmpR (STY4294) & $\begin{array}{c}\text { Envelope stress response. Osmolarity and acid resistance [69,70]; } \\
\text { virulence [71], SPI-1 and SPI-2 control [72-75], Vi capsule activation } \\
{[13,14] \text {; adhesion and invasion [76] }}\end{array}$ \\
\hline PgtB (STY2634) & PgtA (STY2633) & Phosphoglycerate transport [77] \\
\hline PhoR (STY0433) & PhoB (STY0432) & Inorganic phosphate assimilation [78]; SPI-1 regulation [79] \\
\hline PhoQ (STY1270) & PhoP (STY1271) & $\begin{array}{c}\text { Global virulence regulator [80]; Magnesium transport [81]; AMR } \\
\text { [82-84]; invasion [85]; survival in macrophages [80] }\end{array}$ \\
\hline PmrB (STY4490) & PmrA (STY4491) & $\begin{array}{c}\text { LPS modification, AMR resistance, virulence [27,86]; SPI-2 } \\
\text { repression [87] }\end{array}$ \\
\hline QseC (STY3355) & QseB (STY3354) & $\begin{array}{l}\text { Motility, invasion [27], macrophage survival [25], virulence } \\
{[25,88,89]}\end{array}$ \\
\hline QseE (STY2811) & QseF (STY2809) & Invasion and intramacrophage replication [25]; virulence [25] \\
\hline RcsC (STY2496) & RcsB (STY2495) & $\begin{array}{l}\text { Cell envelope stress response, Vi capsule activation [16]; virulence } \\
\text { [90]; AMR [91]; LPS modifications; oxidative and acidic stress [92]; } \\
\text { invasion [17] }\end{array}$ \\
\hline RstB (STY1651) & RstA (STY1647) & Motility [93]; iron acquisition $[94,95]$ \\
\hline BarA (STY3096) & SirA (STY2155) & $\begin{array}{l}\text { Virulence [96], SPI-1 [97], SPI-2 [97], motility [98], Vi capsule [99]; } \\
\text { invasion [100] }\end{array}$ \\
\hline SsrA (STY1728) & SsrB (STY1729) & SPI-2 regulator [11,101], oxidative stress [102]; SPI-1 repression [103] \\
\hline TctE (STY2903) & TctD (STY2904) & Tricarboxylate transport [104] \\
\hline TorS (STY3951) & TorR (STY3954) & Trimethylamine-N-oxide respiration (anaerobic) ${ }^{a}$ [105] \\
\hline TtrS (STY1735) & TtrR (STY1733) & Tetrathionate respiration [106] \\
\hline UhpB (STY3993) & UhpA (STY3992) & Hexose phosphate transport [28], sulfur assimilation [29] \\
\hline YehU (STY2389) & YehT (STY2388) & $\begin{array}{l}\text { Poorly characterized, regulation of the carbon starvation protein } \\
\qquad \text { (CstA) [107] }\end{array}$ \\
\hline
\end{tabular}

\footnotetext{
${ }^{\text {a }}$ Role in Escherichia coli.
} 


\subsection{Adhesion, Invasion, and Replication in Epithelial Cells}

Passage through the intestinal epithelial cell barrier is a key step in the pathogenesis of $S$. Typhi. We used infection of epithelial cells to evaluate adhesion, invasion, and replication effects of the TCS mutant of $S$. Typhi in these cell type. The wild-type $S$. Typhi ISP1820 strain was used as the reference control and its isogenic invA (SPI-1)/ssrB (SPI-2) mutant (here referred as $\triangle$ SPIs) were used as a low virulence control, as this strain exhibits impaired host cell entry.

The adhesion level for the different TCS mutants ranged from 45 to $144 \%$ of the wild-type (Figure 1A). There were 5 mutants that showed a significant change in adherence compared to the wild-type strain. Three mutants (cheY, ompR and $p g t A$ ) were less adherent and 2 mutants (narP and $r c s B$ ) were more adherent. The $\operatorname{omp} R$ was the least adherent, whereas the $r c s B$ mutant had the highest level of cell adherence.

For the cell invasion phenotype, differences in invasion varied from 7 to $370 \%$ of the wild-type, and several mutants (16/30) showed a significant difference in cell invasion compared to the wild-type strain. Seven mutants showed increased invasion (cheY, citB, narP, pgt $A, p m r A, q s e B$ and $r c s B$ ) and 9 showed decreased invasion $(\operatorname{arc} A, b a e R, c p x R, o m p R, p h o P, q s e F$, sir $A, t c t D$ and torR) (Figure 1B). The negative control ( $\triangle \mathrm{SPIs}$ ) showed only $1.3 \%$ invasion compared to the wild-type, as expected. The TCS mutant demonstrating the most decreased invasion was sir $A$ and the mutant with the highest increased invasion was $r c s B$.

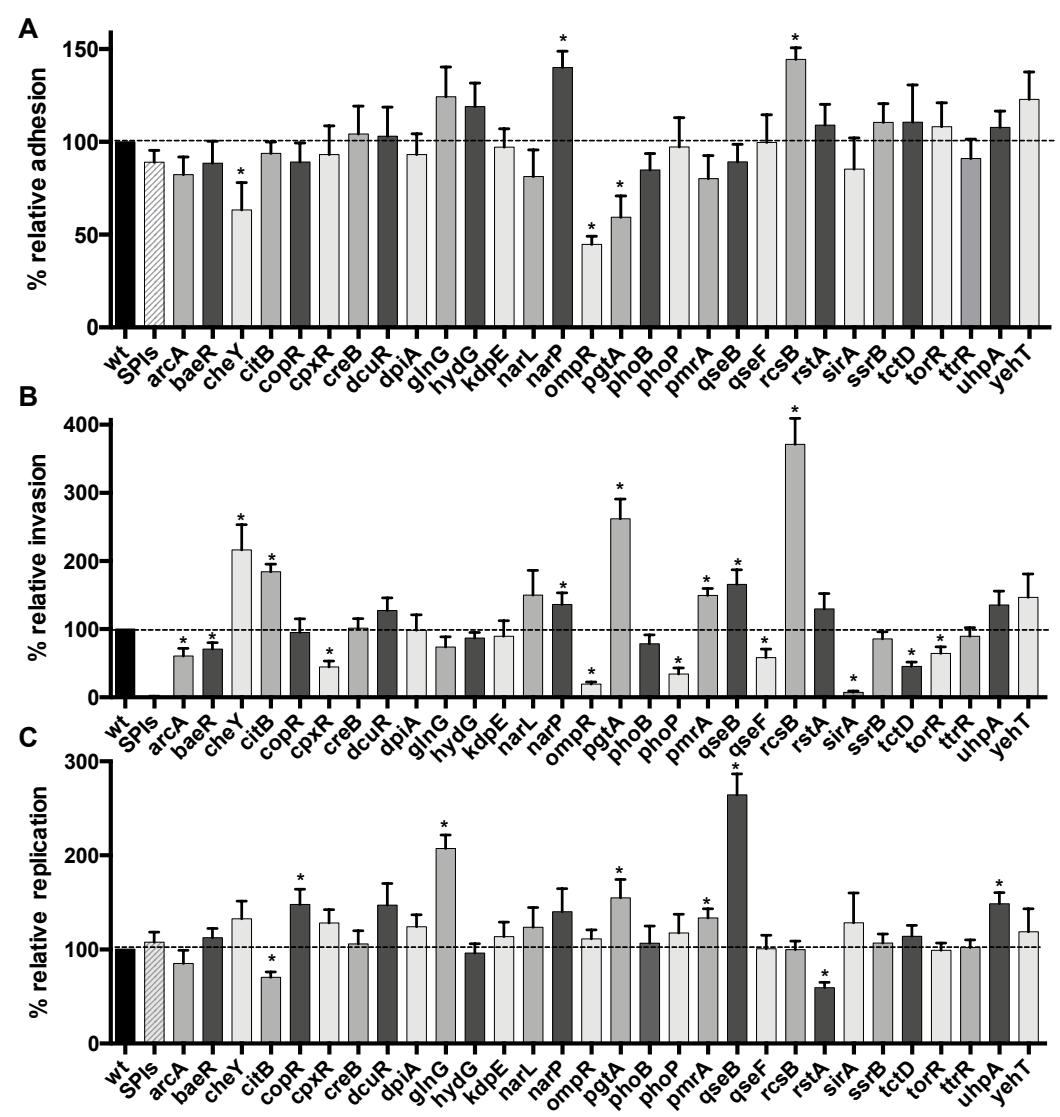

Figure 1. Effect of loss of TCS response regulators on interaction with human epithelial cells. INT-407 epithelial cells were infected with $S$. Typhi wild-type strain and the isogenic RR mutants, and the level of bacteria associated with cells was determined upon adherence $(90 \mathrm{~min})(\mathbf{A})$, invasion (180 $\mathrm{min})(\mathbf{B})$, or after $18 \mathrm{~h}(\mathrm{C})$. All assays were conducted in triplicate and repeated independently at least three times. The results are expressed as the mean \pm SEM of the replicate experiments. Significant differences $\left({ }^{*} p<0.0001\right)$ in the levels recovered as compared to the wild-type were determined by the Student's unpaired $t$-test. The dashed line corresponds to the wild-type level. 
For intracellular replication, the range was from 70 to $264 \%$ of the wild-type. There were 8 mutants demonstrating significantly different levels of replication, 6 that were higher $(\operatorname{cop} R, g \ln G, p g t A, p m r A$, $q s e B$, and $u h p A$ ) and 2 that were lower (citB and $r s t A$ ) than the wild-type control (Figure 1C). The rst $A$ mutant had the greatest decrease, whereas the qseB mutant had the highest level of replication in epithelial cells. Interestingly, several mutants that were defective in invasion were able to replicate similarly to the wild-type.

\subsection{Uptake and Survival in Macrophages}

Some TCSs are important for survival of Salmonella inside macrophages, and survival within these cells represents a crucial step in the pathogenesis and virulence of $S$. Typhi to disseminate systemically. Thus, we investigated the role of each TCS in uptake and survival in macrophages. The wild-type S. Typhi ISP1820 strain was used as the reference control and the phoP24 isogenic mutant (PhoP constitutive) [108], known to be defective in virulence and macrophages survival [109], was used as a low virulence control. This control was chosen as the isogenic $i n v A$ (SPI-1)/ssrB (SPI-2) mutant ( $\triangle$ SPIs) to survive as the wild-type strain in macrophage [23]. The level of internalization by macrophage varied from between 76 to $404 \%$ of the wild-type (Figure 2A). There were 10 mutants with a significant difference in uptake by macrophage compared to the wild-type strain. Seven of the mutants showed increased uptake ( $\operatorname{arc} A, k d p E, \operatorname{nar} L, \operatorname{nar} P, \operatorname{omp} R, \operatorname{pgt} A$, and $\operatorname{rcs} B$ ) and three mutants $(c p x R, d c u R$, and $g \ln G)$ showed decreased macrophage uptake. The $g \ln G$ mutant demonstrated the lowest level of uptake and the $r c s B$ mutant showed the highest level of uptake by macrophage.

The level of survival in macrophages ranged from 29 to $249 \%$ of the wild-type (Figure 2B). There were 16 mutants with a significant difference in survival compared to the wild-type strain, 6 showed an increased survival $(\operatorname{cop} R, p m r A, r c s B$, sir $A, t c t D$, and torR) and 10 demonstrated a decreased survival ( $\operatorname{arc} A, b a e R, c h e Y, c i t B, c p x R, d p i A, k d p E, n a r P, o m p R$, and $p h o P)$. The phoP mutant demonstrated the lowest survival and the $r c s B$ mutant had the highest level of survival in macrophage.

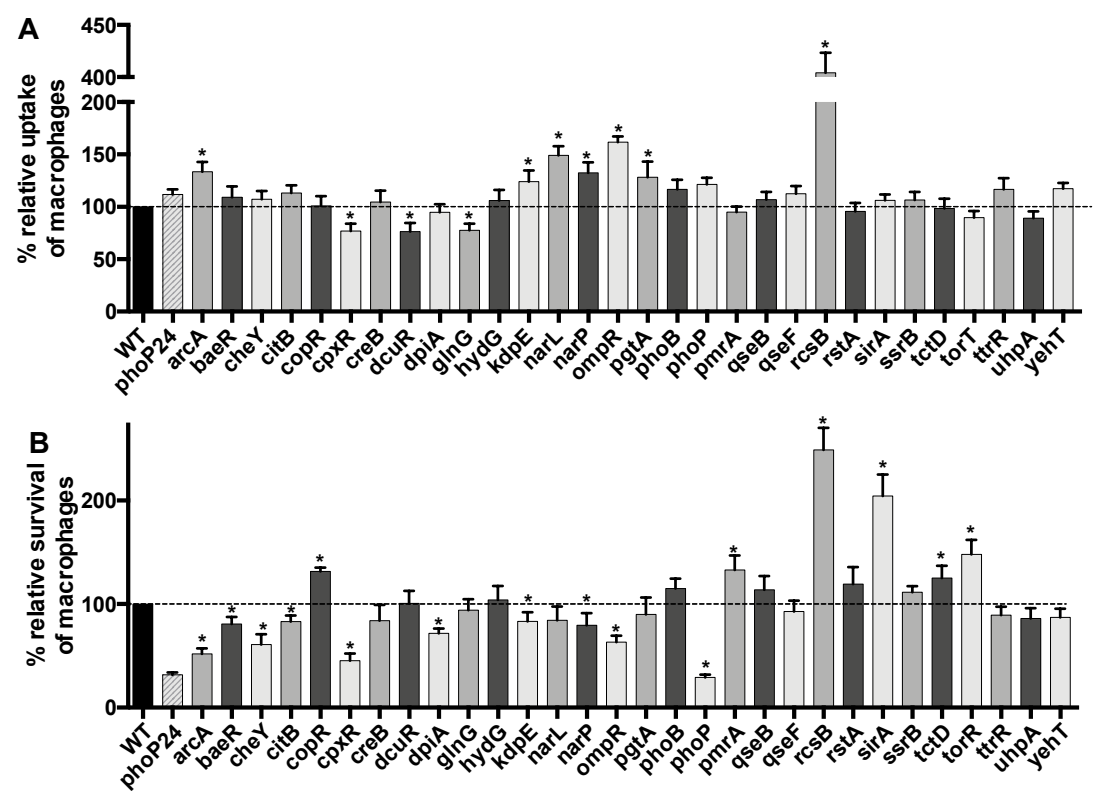

Figure 2. Effect of loss of TCS response regulators during interaction with human macrophages. THP-1 cells were differentiated into macrophages and infected with $S$. Typhi wild-type strain and the isogenic RR mutants. The level of bacterial uptake (phagocytosis) (A) and the level of survival after $18 \mathrm{~h}$ infection (B) were determined. All assays were conducted in duplicate and repeated independently at least three times. The results are expressed as the mean \pm SEM of replicate experiments. Significant differences $\left({ }^{*} p<0.0001\right)$ as compared to wild-type were determined by the Student's unpaired $t$-test. The dashed line corresponds to the wild-type level. 


\subsection{Complementation}

In order to confirm that the phenotypic difference was associated with the RR mutation, we selected 4 mutants that were strongly under- or over-represented compared to the wild-type strain in invasion or survival level in macrophages. The $\operatorname{cpxR}$, ompR, $r c s B$, and $\operatorname{sir} A$ mutants were complemented with a wild-type copy of the gene on a low-copy vector. Interactions with epithelial cells and macrophages were evaluated. The wild-type levels association with cells were restored in the complemented strains (Figure 3).
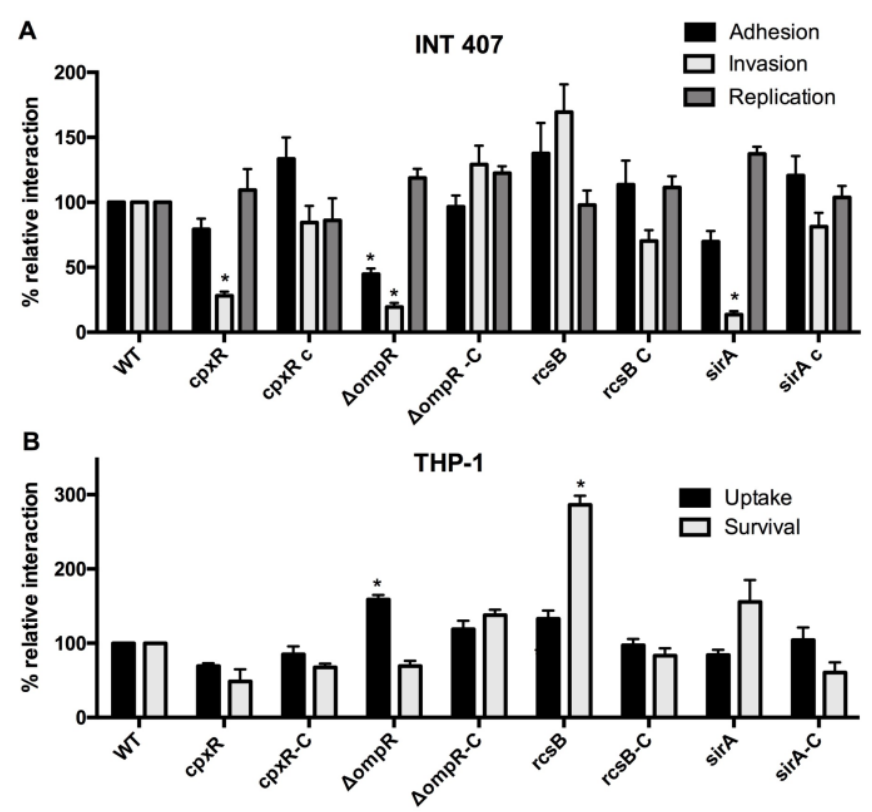

Figure 3. Complementation. Epithelial INT-407 cells (A) and THP-1 macrophages (B) were infected with $S$. Typhi wild-type strain, the $\operatorname{cpxR}, \operatorname{ompR}, r c s B$, and $\operatorname{sir} A$ mutants and complemented mutants with a wild-type copy on a low-copy vector. All assays were conducted in triplicate and repeated independently at least three times. The results are expressed as the mean \pm SEM of the replicate experiments. Significant differences $\left.{ }^{*} p<0.0001\right)$ in the level between the wild-type and the mutant were determined by the Student's unpaired $t$-test. The dashed line corresponds to the wild-type level.

\subsection{Impact of the Vi Antigen}

It was previously demonstrated that RscB and OmpR regulate the Vi capsule $[14-17,19,20]$. As these TCS showed strong phenotypes, often opposite, except for phagocytosis, we investigated the role of the Vi antigen during host cell interaction. We have constructed a tviB mutant as well as a double tviB-ompR and a double tviB-rcsB mutant and evaluated these strains with epithelial cells and macrophages (Figure 4). The lower level of adhesion to epithelial cells observed for the ompR mutant was specific to $o m p R$ as the tviB mutant was not significantly different than the wild-type, whereas the double tviB-ompR was similar to the $\operatorname{ompR}$ mutant. Similarly, the high level of invasion of epithelial cells observed for the $r c s B$ mutant was specific to the $r \operatorname{cs} B$ mutation as the mutant and the double mutant tviB-rcsB were both significantly different than the wild-type but not the tviB mutant. The loss of the Vi antigen did not increase the phagocytosis and survival level in macrophages, suggesting that the phenotypes observed were specific to the $\operatorname{mp} R$ and the $r c s B$ mutation. We have confirmed by immuno-staining that the $\operatorname{ompR}, r c s B$, and tviB mutants did not express the Vi antigen compared to the wild-type strain and other mutants (Figure 4C). 
A

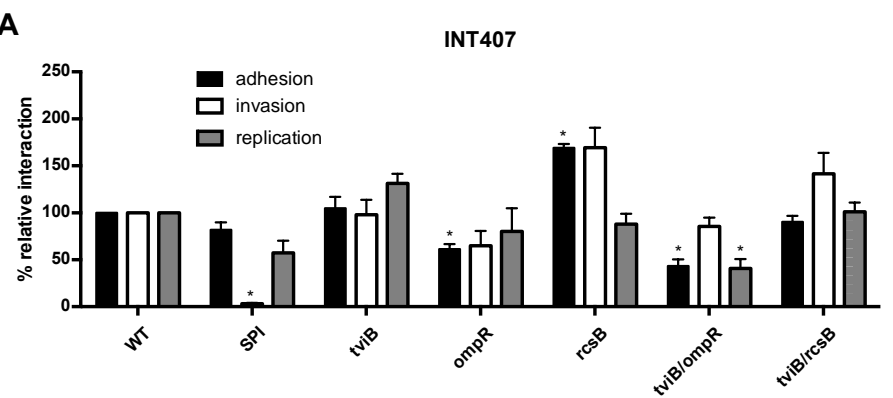

B
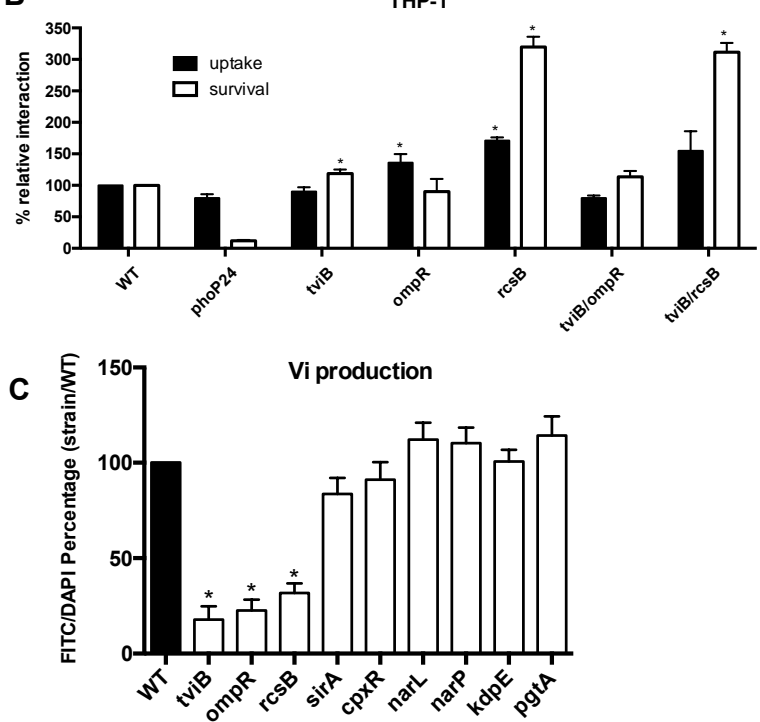

Figure 4. Role of Vi capsule. Epithelial INT-407 cells (A) and THP-1 macrophages (B) were infected with $S$. Typhi wild-type strain, the $t v i B, o m p R, r c s B$ and the double mutant tviB-ompR and tviB-rcsB mutants. (C) Production of the Vi antigen by immuno-staining. All assays were conducted in triplicate and repeated independently at least three times. The results are expressed as the mean \pm SEM of the replicate experiments. Significant differences $\left({ }^{*} p<0.0001\right)$ in the level between the wild-type and the mutant were determined by the Student's unpaired $t$-test.

\subsection{Strain Specificity}

As all mutants were tested in S. Typhi strain ISP1820, we also investigated if the ompR phenotype was conserved in another $S$. Typhi strain. We generated an $o m p R$ deletion in $S$. Typhi Ty2, and this mutant also showed decreased infection of epithelial cells or macrophages (Figure 5).
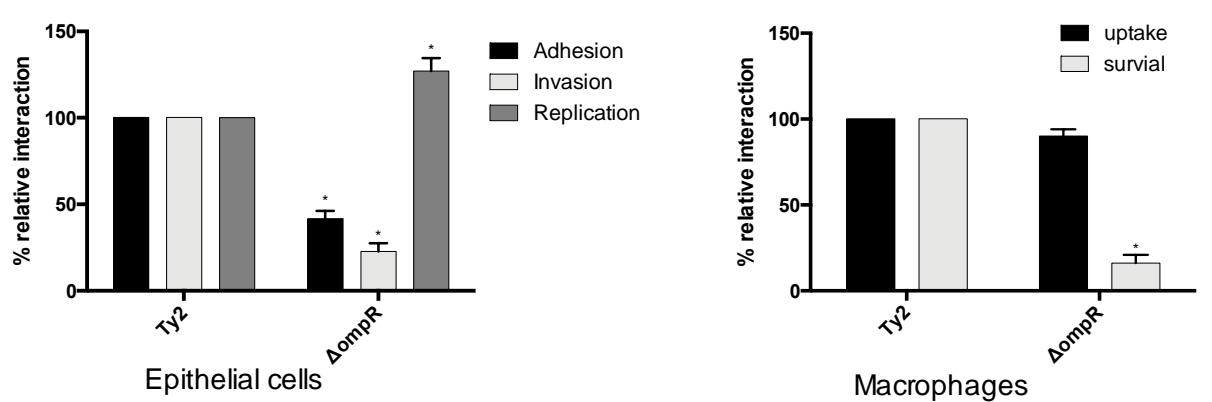

Figure 5. Role of $\operatorname{mom}_{\mathrm{N}} \mathrm{m}$ mutant in S. Typhi strain Ty2. Epithelial INT-407 cells and THP-1 macrophages were infected with $S$. Typhi Ty2 strain and its isogenic ompR mutant. All assays were conducted in triplicate and repeated independently at least three times. The results are expressed as the mean \pm SEM of the replicate experiments. Significant differences $\left({ }^{*} p<0.05\right)$ compared to the wild-type were determined by the Student's unpaired $t$-test. 
Then, as the $\operatorname{cpxR}$ mutant was found to be significantly less invasive than the wild-type strain in $S$. Typhi, but was able to invade and replicate in epithelial cells at levels comparable to the wild-type strain in S. Typhimurium [53,76], we constructed this mutant in S. Typhimurium SL1344 and investigated its interaction with cells (Figure 6). During interaction with epithelial cells, the $c p x R$ mutant of $S$. Typhimurium was similar to the wild-type strain, suggesting that the effect is strain-specific to $S$. Typhi. There was also no difference between the wild-type and the SL1344 cpxR mutant when tested in the murine macrophages RAW264.7.

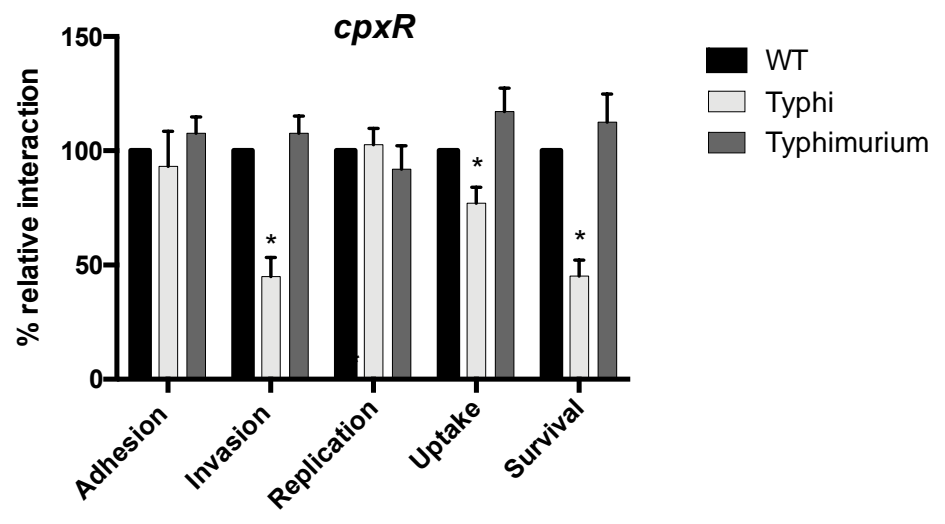

Figure 6. Comparison of the $c p x R$ mutant of $S$. Typhi and $S$. Typhimurium. Epithelial INT-407 cells and THP-1 macrophages were infected with S. Typhi ISP1820 strain and S. Typhimurium SL1344 and their isogenic cpxR mutant. Both WT strains are settled at 100 percent. All assays were conducted in triplicate and repeated independently at least three times. The results are expressed as the mean \pm SEM of the replicate experiments. Significant differences $\left({ }^{*} p<0.0001\right)$ compared to the wild-type were determined by the Student's unpaired $t$-test.

\section{Discussion}

TCS are usually the first to detect a perturbation in the intracellular or extracellular environment and will react quickly to modify bacterial gene expression. They are involved in sensing a variety of signals $(\mathrm{pH}$, ions, nutrients, stress, etc.). Therefore, TCS are critical for bacterial adaptation and survival. Here, we have identified 30 TCS in the genome of $S$. Typhi and summarized their putative function and role in Salmonella (Table 1). We have deleted each of the TCS regulator encoding genes from $S$. Typhi and tested interactions with human epithelial cells (adhesion, invasion, and replication) and macrophages (uptake and survival), which constitute two important niches of $S$. Typhi infection. Moreover, these mutants represent important tools to advance our knowledge of $S$. Typhi pathogenesis by investigating their roles during interactions with cells or under different environmental conditions.

All the TCS mutants grew similarly to the wild-type strain in liquid culture. Most of the TCS mutants (24/30) showed a significant difference compared to the wild-type strain during at least one step of infection (adhesion, invasion, replication, uptake, or survival) (Table 2). There were 9 phenotypes previously associated with 8 TCS in $S$. Typhimurium that were confirmed in S. Typhi $(\operatorname{arc} A$, cheY, phoP, qseB, qseF, $r c s B$, sir $A$, and yehT) (Table 2). Interestingly, several of the TCS previously associated with $S$. Typhimurium virulence in mice (cheY, cpxR, narP, ompR, phoP, qseB, qseF, rcsB, sirA, and ssrB) display a phenotype during host cell interaction with $S$. Typhi, except for $c p x R$ and $s s r B$, see below (Table 2). An important aspect of this study was the identification of 32 new phenotypes associated with $S$. Typhi TCS mutants (Table 2). Interestingly, the $c p x R$ mutant had phenotypes distinct from $S$. Typhimurium found in the literature (Table 2). The $S$. Typhimurium cpxR mutant was not affected for invasion or intracellular replication in epithelial cells (HEp2 and Caco-2) or survival in RAW264.7 macrophages [53], while the $S$. Typhi cpxR mutant was defective in invasion of INT407 cells and survival in THP-1 macrophages (Table 2). Thus, we have deleted cpxR in S. Typhimurium SL1344 and evaluated its level of adhesion, invasion, and replication in epithelial cells and in macrophages 
(Figure 6). No significant difference between the wild-type was observed, confirming a difference in the role of CpxR between $S$. Typhi and $S$. Typhimurium.

Table 2. Phenotype of regulator mutant during interaction with host.

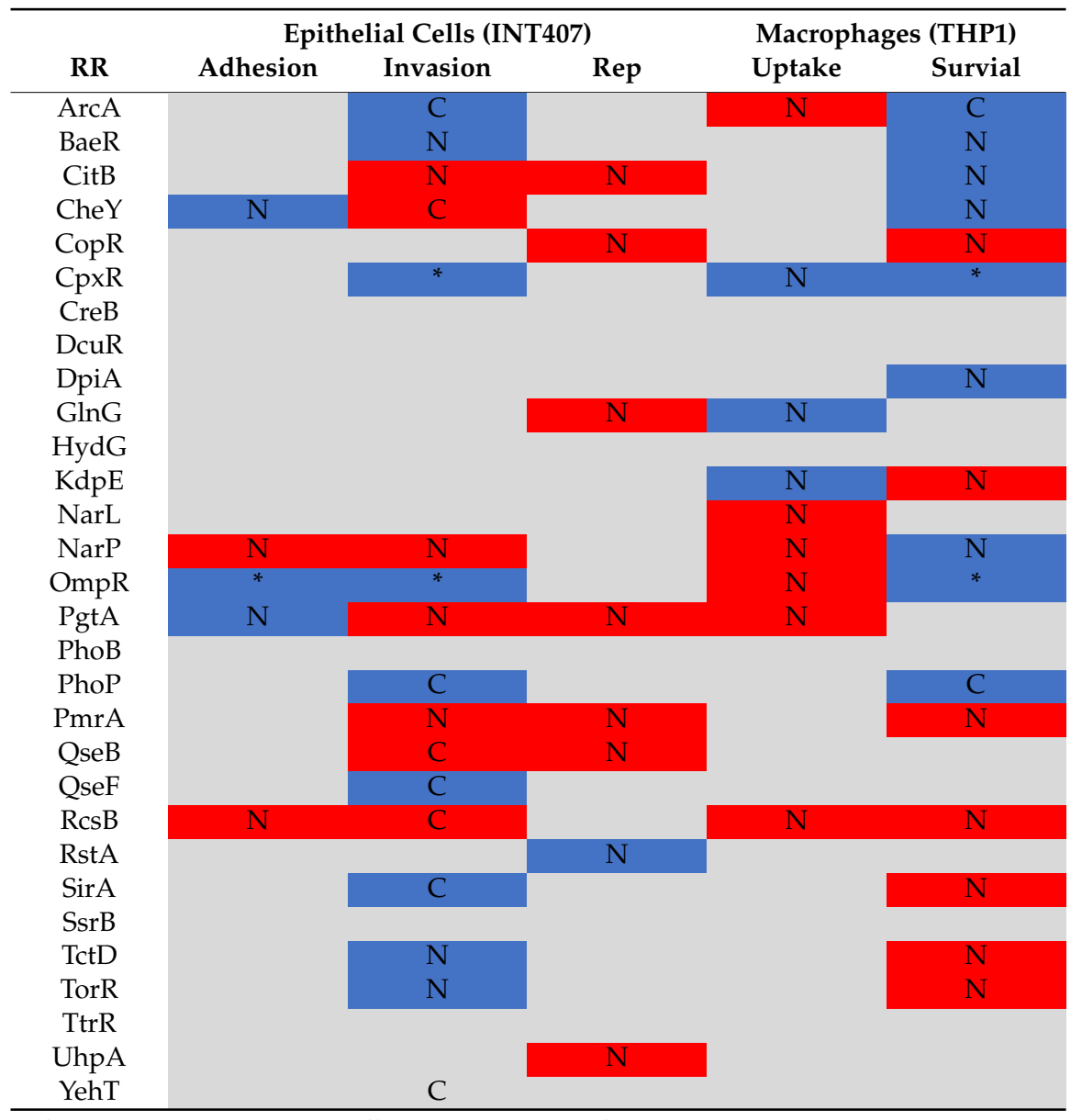

Blue $=$ significantly lower; Grey $=$ no difference, Red $=$ significantly higher than the wild-type. $\mathrm{C}=$ confirmed phenotype; $\mathrm{N}=$ new phenotype; ${ }^{*}=$ divergent phenotype.

Six RR mutants, $\operatorname{cre} B, h y d G, \operatorname{phoB}, \operatorname{ssr} B, \operatorname{ttr} R$ and yehT were similar to the wild-type strain in all conditions tested. The mutation of 4 TCS ( $c r e B, h y d G, p h o B, s s r B)$ in $S$. Dublin also resulted in a phenotype similar to the wild-type strain during infection of epithelial cells [110]. The deletion of the Ttr system of $S$. Dublin caused a higher level of invasion, but in $S$. Typhi, the $t$ tr $S$ sensor is a pseudogene (see below), which may explain why no phenotypes were observed. It may be surprising that the SsrAB system, which is the principal regulator of SPI-2, demonstrated no defect, but we have previously demonstrated that the entire SPI-2 deletion was not essential for S. Typhi survival in macrophages [23], and SPI-2 was not required for $S$. Typhi infection in a humanized mice model [111], highlighting one of the major differences with $S$. Typhimurium.

$S$. Typhi has evolved as a human-restricted pathogen without any known environmental niche. This specialization is associated with genome degradation, as up to $5 \%$ of its genome includes predicted open reading frames that have become pseudogenes. There are two TCS that are pseudogenes in $S$. Typhi: TorR and the sensor TtrS. The TtrSR system is involved in tetrathionate respiration in the inflamed gut, which provides a competitive advantage against the intestinal microbiota [112]. However, the production of the Vi capsule by $S$. Typhi prevents intestinal inflammation [9], suggesting that $S$. Typhi does not need the TtrRS system and the ttrR mutant did not show any phenotype in the tested conditions here. The TorSR system is not characterized in Salmonella. In E. coli, TorR activates the transcription of tor $C A D$ [113], which encodes proteins required for anaerobic respiration [114-116]. 
Here, even in the absence of a functional sensor, the tor $R$ mutant was defective in invasion and had a higher level of survival in macrophages.

Epithelial cell invasion was the infection step in epithelial cells where TCS mutants differed significantly when compared to the wild-type, as 16 mutants demonstrated changes in invasion (7 increased invasion and 9 decreased invasion). As expected, the sirA (Salmonella invasion regulator) deletion resulted in decreased invasion, consistent with the role of SirA in inducing SPI-1 [97,117]. The complementation of this mutant restored the wild-type level (Figure 3). By contrast, only 5 mutants were affected in their adhesion level and 8 in intracellular replication, compared to the wild-type. Interestingly, none of the TCS mutants had the same phenotypic pattern (Table 1), except for the 6 aforementioned mutants that did not differ from the wild-type. This emphasizes the diversity of TCS used to respond to environmental changes as well as the specificity of each system, as each TCS is unique.

The $r c s B$ mutant showed increases in cell interactions for almost all tested conditions, except for intracellular replication in epithelial cells. RcsB belongs to the Rcs phosphorelay, a complex TCS with three members, $\mathrm{RcsC}$, RcsD, and RcsB, and several accessory proteins involved in the stress envelope response. RcsB was shown to repress important virulence factors, including fimbriae, SPI-1, and also activation expression of the Vi capsule [16,90]. Thus, some virulence genes are expressed in the $r c s B$ mutant, which lead to increased adhesion and invasion and the Vi capsule is repressed, which increased phagocytosis by these cells [118].

The $\operatorname{ompR}$ mutant showed the lowest level of adhesion and one of the lowest levels of invasion (Figure 1). These defects were restored by the addition of a wild-type copy of ompR (Figure 3). The motility of the $o m p R$ mutant was also reduced to $85 \%$ of the wild-type. An ompR mutant was attenuated in S. Typhimurium [71] and OmpR was associated with the activation of SPI-2 [73-75] and motility genes [119]. This regulation pattern is exactly the opposite of the Rcs system, which may explain why these mutants have strong and opposite phenotypes. These phenotypes are specific to each mutation and did not involve the Vi capsule.

\section{Conclusions}

Virulence genes expression needed to be tightly regulated in order for $S$. Typhi to adapt and survive within the host. TCS participate in the regulation of several virulence factors and we have shown that several TCS contribute to adhesion, invasion, replication, uptake, and survival of $S$. Typhi. Distinct phenotypes of the CpxR mutant of $S$. Typhi compared to $S$. Typhimurium may reveal fundamental regulatory differences associated with $S$. Typhi niche specialization. Further characterization of the regulons associated with TCS involved in virulence and identification of the signals required for their activation will be important to understand S. Typhi pathogenesis. This will help to identify and develop strategies to prevent and or to reduce typhoid infections.

Supplementary Materials: The following are available online at http://www.mdpi.com/2076-2607/8/5/722/s1: Table S1: Bacterial strains used in this study; Table S2: Plasmids used in this study; Table S3: Primers used in this study.

Author Contributions: Conceptualization, C.M.-L. and F.D.; methodology, C.M.-L., M.K. and K.D.; validation, C.M.-L., M.K., K.D. and F.D.; formal analysis, C.M.-L., F.D.; resources, F.D.; writing-original draft preparation, C.M.-L.; writing-review and editing, C.M.-L., M.K., K.D. and F.D.; supervision, F.D.; funding acquisition, F.D. All authors have read and agreed to the published version of the manuscript.

Funding: This research was supported by the Natural Sciences and Engineering Research Council of Canada (FD: Discovery grant 25114-12).

Conflicts of Interest: The authors declare no conflict of interest.

\section{References}

1. Beier, D.; Gross, R. Regulation of bacterial virulence by two-component systems. Curr. Opin. Microbiol. 2006, 9, 143-152. [CrossRef] [PubMed] 
2. Stock, A.M.; Robinson, V.L.; Goudreau, P.N. Two-component signal transduction. Annu. Rev. Biochem. 2000, 69, 183-215. [CrossRef] [PubMed]

3. Parkinson, J.S.; Kofoid, E.C. Communication modules in bacterial signaling proteins. Annu. Rev. Genet. 1992, 26, 71-112. [CrossRef] [PubMed]

4. Gibani, M.M.; Britto, C.; Pollard, A.J. Typhoid and paratyphoid fever: A call to action. Curr. Opin. Infect. Dis. 2018, 31, 440-448. [CrossRef]

5. Audia, J.P.; Webb, C.C.; Foster, J.W. Breaking through the acid barrier: An orchestrated response to proton stress by enteric bacteria. Int. J. Med. Microbiol. 2001, 291, 97-106. [CrossRef]

6. Tiwari, R.P.; Sachdeva, N.; Hoondal, G.S.; Grewal, J.S. Adaptive acid tolerance response in Salmonella enterica serovar Typhimurium and Salmonella enterica serovar Typhi. J. Basic Microbiol. 2004, 44, 137-146. [CrossRef]

7. Lostroh, C.P.; Lee, C.A. The Salmonella pathogenicity island-1 type III secretion system. Microbes Infect. 2001, 3, 1281-1291. [CrossRef]

8. Lara-Tejero, M.; Galan, J.E. The Injectisome, a Complex Nanomachine for Protein Injection into Mammalian Cells. EcoSal Plus 2019, 8. [CrossRef]

9. Raffatellu, M.; Chessa, D.; Wilson, R.P.; Dusold, R.; Rubino, S.; Baumler, A.J. The Vi capsular antigen of Salmonella enterica serotype Typhi reduces Toll-like receptor-dependent interleukin-8 expression in the intestinal mucosa. Infect. Immun. 2005, 73, 3367-3374. [CrossRef]

10. Waterman, S.R.; Holden, D.W. Functions and effectors of the Salmonella pathogenicity island 2 type III secretion system. Cell. Microbiol. 2003, 5, 501-511. [CrossRef]

11. Hensel, M.; Shea, J.E.; Waterman, S.R.; Mundy, R.; Nikolaus, T.; Banks, G.; Vazquez-Torres, A.; Gleeson, C.; Fang, F.C.; Holden, D.W. Genes encoding putative effector proteins of the type III secretion system of Salmonella pathogenicity island 2 are required for bacterial virulence and proliferation in macrophages. Mol. Microbiol. 1998, 30, 163-174. [CrossRef] [PubMed]

12. Parry, C.M.; Hien, T.T.; Dougan, G.; White, N.J.; Farrar, J.J. Typhoid fever. N. Engl. J. Med. 2002, 347, 1770-1782. [CrossRef] [PubMed]

13. Pickard, D.; Li, J.; Roberts, M.; Maskell, D.; Hone, D.; Levine, M.; Dougan, G.; Chatfield, S. Characterization of defined ompR mutants of Salmonella typhi: ompR is involved in the regulation of Vi polysaccharide expression. Infect. Immun. 1994, 62, 3984-3993. [CrossRef] [PubMed]

14. Santander, J.; Roland, K.L.; Curtiss, R., 3rd. Regulation of Vi capsular polysaccharide synthesis in Salmonella enterica serotype Typhi. J. Infect. Dev. Ctries 2008, 2, 412-420.

15. Virlogeux, I.; Waxin, H.; Ecobichon, C.; Lee, J.O.; Popoff, M.Y. Characterization of the rcsA and rcsB genes from Salmonella typhi: rcsB through tviA is involved in regulation of Vi antigen synthesis. J. Bacteriol. 1996, 178, 1691-1698. [CrossRef] [PubMed]

16. Winter, S.E.; Winter, M.G.; Thiennimitr, P.; Gerriets, V.A.; Nuccio, S.P.; Russmann, H.; Baumler, A.J. The TviA auxiliary protein renders the Salmonella enterica serotype Typhi RcsB regulon responsive to changes in osmolarity. Mol. Microbiol. 2009, 74, 175-193. [CrossRef]

17. Arricau, N.; Hermant, D.; Waxin, H.; Ecobichon, C.; Duffey, P.S.; Popoff, M.Y. The RcsB-RcsC regulatory system of Salmonella typhi differentially modulates the expression of invasion proteins, flagellin and $\mathrm{Vi}$ antigen in response to osmolarity. Mol. Microbiol. 1998, 29, 835-850. [CrossRef]

18. Fowler, C.C.; Galan, J.E. Decoding a Salmonella Typhi Regulatory Network that Controls Typhoid Toxin Expression within Human Cells. Cell Host Microbe 2018, 23, 65-76, e66. [CrossRef]

19. Faucher, S.P.; Forest, C.; Beland, M.; Daigle, F. A novel PhoP-regulated locus encoding the cytolysin ClyA and the secreted invasin TaiA of Salmonella enterica serovar Typhi is involved in virulence. Microbiology 2009, 155, 477-488. [CrossRef]

20. Charles, R.C.; Harris, J.B.; Chase, M.R.; Lebrun, L.M.; Sheikh, A.; LaRocque, R.C.; Logvinenko, T.; Rollins, S.M.; Tarique, A.; Hohmann, E.L.; et al. Comparative proteomic analysis of the PhoP regulon in Salmonella enterica serovar Typhi versus Typhimurium. PLoS ONE 2009, 4, e6994. [CrossRef]

21. Sheikh, A.; Charles, R.C.; Sharmeen, N.; Rollins, S.M.; Harris, J.B.; Bhuiyan, M.S.; Arifuzzaman, M.; Khanam, F.; Bukka, A.; Kalsy, A.; et al. In vivo expression of Salmonella enterica serotype Typhi genes in the blood of patients with typhoid fever in Bangladesh. PLoS Negl. Trop. Dis. 2011, 5, e1419. [CrossRef] [PubMed] 
22. Hohmann, E.L.; Oletta, C.A.; Killeen, K.P.; Miller, S.I. phoP/phoQ-deleted Salmonella typhi (Ty800) is a safe and immunogenic single-dose typhoid fever vaccine in volunteers. J. Infect. Dis. 1996, 173, 1408-1414. [CrossRef] [PubMed]

23. Forest, C.G.; Ferraro, E.; Sabbagh, S.C.; Daigle, F. Intracellular survival of Salmonella enterica serovar Typhi in human macrophages is independent of Salmonella pathogenicity island (SPI)-2. Microbiology 2010, 156, 3689-3698. [CrossRef] [PubMed]

24. Leclerc, G.J.; Tartera, C.; Metcalf, E.S. Environmental regulation of Salmonella typhi invasion-defective mutants. Infect. Immun. 1998, 66, 682-691. [CrossRef]

25. Moreira, C.G.; Sperandio, V. Interplay between the QseC and QseE bacterial adrenergic sensor kinases in Salmonella enterica serovar Typhimurium pathogenesis. Infect. Immun. 2012, 80, 4344-4353. [CrossRef]

26. Bearson, B.L.; Bearson, S.M. The role of the QseC quorum-sensing sensor kinase in colonization and norepinephrine-enhanced motility of Salmonella enterica serovar Typhimurium. Microb. Pathog. 2008, 44, 271-278. [CrossRef]

27. Ji, Y.; Li, W.; Zhang, Y.; Chen, L.; Zhang, Y.; Zheng, X.; Huang, X.; Ni, B. QseB mediates biofilm formation and invasion in Salmonella enterica serovar Typhi. Microb. Pathog. 2017, 104, 6-11. [CrossRef]

28. Island, M.D.; Wei, B.Y.; Kadner, R.J. Structure and function of the uhp genes for the sugar phosphate transport system in Escherichia coli and Salmonella typhimurium. J. Bacteriol. 1992, 174, 2754-2762. [CrossRef]

29. Sheng, X.; Huang, X.; Li, J.; Xie, X.; Xu, S.; Zhang, H.; Xu, H. Regulation of sulfur assimilation pathways in Salmonella enterica serovar Typhi upon up-shift high osmotic treatment: The role of UhpA revealed through transcriptome profiling. Curr. Microbiol. 2009, 59, 628-635. [CrossRef]

30. Wanner, B.L. Is cross regulation by phosphorylation of two-component response regulator proteins important in bacteria? J. Bacteriol. 1992, 174, 2053-2058. [CrossRef]

31. Hone, D.M.; Harris, A.M.; Chatfield, S.; Dougan, G.; Levine, M.M. Construction of genetically defined double aro mutants of Salmonella typhi. Vaccine 1991, 9, 810-816. [CrossRef]

32. O'Callaghan, D.; Charbit, A. High efficiency transformation of Salmonella typhimurium and Salmonella typhi by electroporation. Mol. Gen. Genet. 1990, 223, 156-158. [CrossRef] [PubMed]

33. Parkhill, J.; Dougan, G.; James, K.D.; Thomson, N.R.; Pickard, D.; Wain, J.; Churcher, C.; Mungall, K.L.; Bentley, S.D.; Holden, M.T.; et al. Complete genome sequence of a multiple drug resistant Salmonella enterica serovar Typhi CT18. Nature 2001, 413, 848-852. [CrossRef] [PubMed]

34. Forest, C.; Faucher, S.; Poirier, K.; Houle, S.; Dozois, C.; Daigle, F. Contribution of the stg fimbrial operon of Salmonella enterica serovar Typhi during interaction with human cells. Infect. Immun. 2007, 75, 5264-5271. [CrossRef]

35. Ho, S.N.; Hunt, H.D.; Horton, R.M.; Pullen, J.K.; Pease, L.R. Site-directed mutagenesis by overlap extension using the polymerase chain reaction. Gene 1989, 77, 51-59. [CrossRef]

36. Daigle, F.; Graham, J.; Curtiss, R., 3rd. Identification of Salmonella typhi genes expressed within macrophages by selective capture of transcribed sequences (SCOTS). Mol. Microbiol. 2001, 41, 1211-1222. [CrossRef]

37. Sabbagh, S.C.; Lepage, C.; McClelland, M.; Daigle, F. Selection of Salmonella enterica serovar Typhi genes involved during interaction with human macrophages by screening of a transposon mutant library. PLoS ONE 2012, 7, e36643. [CrossRef]

38. Lu, S.; Killoran, P.B.; Fang, F.C.; Riley, L.W. The global regulator ArcA controls resistance to reactive nitrogen and oxygen intermediates in Salmonella enterica serovar Enteritidis. Infect. Immun. 2002, 70, 451-461. [CrossRef]

39. Morales, E.H.; Calderon, I.L.; Collao, B.; Gil, F.; Porwollik, S.; McClelland, M.; Saavedra, C.P. Hypochlorous acid and hydrogen peroxide-induced negative regulation of Salmonella enterica serovar Typhimurium ompW by the response regulator ArcA. BMC Microbiol. 2012, 12, 63. [CrossRef]

40. Lim, S.; Yoon, H.; Kim, M.; Han, A.; Choi, J.; Choi, J.; Ryu, S. Hfq and ArcA are involved in the stationary phase-dependent activation of Salmonella pathogenicity island 1 (SPI1) under shaking culture conditions. J. Microbiol. Biotechnol. 2013, 23, 1664-1672. [CrossRef]

41. Evans, M.R.; Fink, R.C.; Vazquez-Torres, A.; Porwollik, S.; Jones-Carson, J.; McClelland, M.; Hassan, H.M. Analysis of the ArcA regulon in anaerobically grown Salmonella enterica sv. Typhimurium. BMC Microbiol. 2011, 11, 58. [CrossRef] 
42. Pardo-Este, C.; Hidalgo, A.A.; Aguirre, C.; Briones, A.C.; Cabezas, C.E.; Castro-Severyn, J.; Fuentes, J.A.; Opazo, C.M.; Riedel, C.A.; Otero, C.; et al. The ArcAB two-component regulatory system promotes resistance to reactive oxygen species and systemic infection by Salmonella Typhimurium. PLoS ONE 2018, 13, e0203497. [CrossRef] [PubMed]

43. Guerrero, P.; Collao, B.; Morales, E.H.; Calderon, I.L.; Ipinza, F.; Parra, S.; Saavedra, C.P.; Gil, F. Characterization of the BaeSR two-component system from Salmonella Typhimurium and its role in ciprofloxacin-induced $m d t A$ expression. Arch. Microbiol. 2012, 194, 453-460. [CrossRef] [PubMed]

44. Appia-Ayme, C.; Patrick, E.; Sullivan, M.J.; Alston, M.J.; Field, S.J.; AbuOun, M.; Anjum, M.F.; Rowley, G. Novel inducers of the envelope stress response BaeSR in Salmonella Typhimurium: BaeR is critically required for tungstate waste disposal. PLoS ONE 2011, 6, e23713. [CrossRef] [PubMed]

45. Bott, M. Anaerobic citrate metabolism and its regulation in enterobacteria. Arch. Microbiol. 1997, 167, 78-88. [CrossRef]

46. Stecher, B.; Hapfelmeier, S.; Muller, C.; Kremer, M.; Stallmach, T.; Hardt, W.D. Flagella and chemotaxis are required for efficient induction of Salmonella enterica serovar Typhimurium colitis in streptomycin-pretreated mice. Infect. Immun. 2004, 72, 4138-4150. [CrossRef]

47. Lee, C.A.; Jones, B.D.; Falkow, S. Identification of a Salmonella typhimurium invasion locus by selection for hyperinvasive mutants. Proc. Natl. Acad. Sci. USA 1992, 89, 1847-1851. [CrossRef]

48. Pezza, A.; Pontel, L.B.; Lopez, C.; Soncini, F.C. Compartment and signal-specific codependence in the transcriptional control of Salmonella periplasmic copper homeostasis. Proc. Natl. Acad. Sci. USA 2016, 113, 11573-11578. [CrossRef]

49. Kato, A.; Higashino, N.; Utsumi, R. Fe(3+)-dependent epistasis between the CpxR-activated loci and the PmrA-activated LPS modification loci in Salmonella enterica. J. Gen. Appl. Microbiol. 2017, 62, 286-296. [CrossRef]

50. Cerminati, S.; Giri, G.F.; Mendoza, J.I.; Soncini, F.C.; Checa, S.K. The CpxR/CpxA system contributes to Salmonella gold-resistance by controlling the GolS-dependent gesABC transcription. Environ. Microbiol. 2017, 19, 4035-4044. [CrossRef]

51. Weatherspoon-Griffin, N.; Zhao, G.; Kong, W.; Kong, Y.; Andrews-Polymenis, H.; McClelland, M.; Shi, Y. The CpxR/CpxA two-component system up-regulates two Tat-dependent peptidoglycan amidases to confer bacterial resistance to antimicrobial peptide. J. Biol. Chem. 2011, 286, 5529-5539. [CrossRef] [PubMed]

52. Lopez, C.; Checa, S.K.; Soncini, F.C. CpxR/CpxA Controls scsABCD Transcription To Counteract Copper and Oxidative Stress in Salmonella enterica Serovar Typhimurium. J. Bacteriol. 2018, 200. [CrossRef] [PubMed]

53. Humphreys, S.; Rowley, G.; Stevenson, A.; Anjum, M.F.; Woodward, M.J.; Gilbert, S.; Kormanec, J.; Roberts, M. Role of the two-component regulator CPxAR in the virulence of Salmonella enterica serotype Typhimurium. Infect. Immun. 2004, 72, 4654-4661. [CrossRef] [PubMed]

54. De la Cruz, M.A.; Perez-Morales, D.; Palacios, I.J.; Fernandez-Mora, M.; Calva, E.; Bustamante, V.H. The two-component system CpxR/A represses the expression of Salmonella virulence genes by affecting the stability of the transcriptional regulator HilD. Front. Microbiol. 2015, 6, 807. [CrossRef] [PubMed]

55. Subramaniam, S.; Muller, V.S.; Hering, N.A.; Mollenkopf, H.; Becker, D.; Heroven, A.K.; Dersch, P.; Pohlmann, A.; Tedin, K.; Porwollik, S.; et al. Contribution of the Cpx envelope stress system to metabolism and virulence regulation in Salmonella enterica serovar Typhimurium. PLoS ONE 2019, 14, e0211584. [CrossRef]

56. Fujimoto, M.; Goto, R.; Haneda, T.; Okada, N.; Miki, T. Salmonella enterica Serovar Typhimurium CpxRA Two-Component System Contributes to Gut Colonization in Salmonella-Induced Colitis. Infect. Immun. 2018, 86. [CrossRef] [PubMed]

57. Avison, M.B.; Horton, R.E.; Walsh, T.R.; Bennett, P.M. Escherichia coli CreBC is a global regulator of gene expression that responds to growth in minimal media. J. Biol. Chem. 2001, 276, 26955-26961. [CrossRef] [PubMed]

58. Scheu, P.D.; Kim, O.B.; Griesinger, C.; Unden, G. Sensing by the membrane-bound sensor kinase DcuS: Exogenous versus endogenous sensing of C(4)-dicarboxylates in bacteria. Future Microbiol. 2010, 5, 1383-1402. [CrossRef]

59. Golby, P.; Davies, S.; Kelly, D.J.; Guest, J.R.; Andrews, S.C. Identification and characterization of a two-component sensor-kinase and response-regulator system (DcuS-DcuR) controlling gene expression in response to C4-dicarboxylates in Escherichia coli. J. Bacteriol. 1999, 181, 1238-1248. [CrossRef] 
60. Miller, C.; Thomsen, L.E.; Gaggero, C.; Mosseri, R.; Ingmer, H.; Cohen, S.N. SOS response induction by beta-lactams and bacterial defense against antibiotic lethality. Science 2004, 305, 1629-1631. [CrossRef]

61. Ferro-Luzzi Ames, G.; Nikaido, K. Nitrogen regulation in Salmonella typhimurium. Identification of an $n t r C$ protein-binding site and definition of a consensus binding sequence. EMBO J. 1985, 4, 539-547. [CrossRef] [PubMed]

62. Klose, K.E.; Mekalanos, J.J. Simultaneous prevention of glutamine synthesis and high-affinity transport attenuates Salmonella typhimurium virulence. Infect. Immun. 1997, 65, 587-596. [CrossRef] [PubMed]

63. Leonhartsberger, S.; Huber, A.; Lottspeich, F.; Bock, A. The hydH/G Genes from Escherichia coli code for a zinc and lead responsive two-component regulatory system. J. Mol. Biol. 2001, 307, 93-105. [CrossRef] [PubMed]

64. Rhoads, D.B.; Waters, F.B.; Epstein, W. Cation transport in Escherichia coli. VIII. Potassium transport mutants. J. Gen. Physiol. 1976, 67, 325-341. [CrossRef]

65. Alegado, R.A.; Chin, C.Y.; Monack, D.M.; Tan, M.W. The two-component sensor kinase KdpD is required for Salmonella typhimurium colonization of Caenorhabditis elegans and survival in macrophages. Cell. Microbiol. 2011, 13, 1618-1637. [CrossRef]

66. Noriega, C.E.; Lin, H.Y.; Chen, L.L.; Williams, S.B.; Stewart, V. Asymmetric cross-regulation between the nitrate-responsive NarX-NarL and NarQ-NarP two-component regulatory systems from Escherichia coli K-12. Mol. Microbiol. 2010, 75, 394-412. [CrossRef]

67. Rabin, R.S.; Stewart, V. Dual response regulators (NarL and NarP) interact with dual sensors (NarX and NarQ) to control nitrate- and nitrite-regulated gene expression in Escherichia coli K-12. J. Bacteriol. 1993, 175, 3259-3268. [CrossRef]

68. Lopez, C.A.; Rivera-Chavez, F.; Byndloss, M.X.; Baumler, A.J. The Periplasmic Nitrate Reductase NapABC Supports Luminal Growth of Salmonella enterica Serovar Typhimurium during Colitis. Infect. Immun. 2015, 83, 3470-3478. [CrossRef]

69. Bang, I.S.; Kim, B.H.; Foster, J.W.; Park, Y.K. OmpR regulates the stationary-phase acid tolerance response of Salmonella enterica serovar typhimurium. J. Bacteriol. 2000, 182, 2245-2252. [CrossRef]

70. Chakraborty, S.; Kenney, L.J. A New Role of OmpR in Acid and Osmotic Stress in Salmonella and E. coli. Front. Microbiol. 2018, 9, 2656. [CrossRef]

71. Dorman, C.J.; Chatfield, S.; Higgins, C.F.; Hayward, C.; Dougan, G. Characterization of porin and ompR mutants of a virulent strain of Salmonella typhimurium: ompR mutants are attenuated in vivo. Infect. Immun. 1989, 57, 2136-2140. [CrossRef] [PubMed]

72. Cameron, A.D.; Dorman, C.J. A fundamental regulatory mechanism operating through OmpR and DNA topology controls expression of Salmonella pathogenicity islands SPI-1 and SPI-2. PLoS Genet. 2012, 8, e1002615. [CrossRef] [PubMed]

73. Lee, A.K.; Detweiler, C.S.; Falkow, S. OmpR regulates the two-component system SsrA-ssrB in Salmonella pathogenicity island 2. J. Bacteriol. 2000, 182, 771-781. [CrossRef] [PubMed]

74. Garmendia, J.; Beuzon, C.R.; Ruiz-Albert, J.; Holden, D.W. The roles of SsrA-SsrB and OmpR-EnvZ in the regulation of genes encoding the Salmonella typhimurium SPI-2 type III secretion system. Microbiology 2003, 149, 2385-2396. [CrossRef] [PubMed]

75. Feng, X.; Oropeza, R.; Kenney, L.J. Dual regulation by phospho-OmpR of ssrA/B gene expression in Salmonella pathogenicity island 2. Mol. Microbiol. 2003, 48, 1131-1143. [CrossRef]

76. Mills, S.D.; Ruschkowski, S.R.; Stein, M.A.; Finlay, B.B. Trafficking of porin-deficient Salmonella typhimurium mutants inside HeLa cells: ompR and envZ mutants are defective for the formation of Salmonella-induced filaments. Infect. Immun. 1998, 66, 1806-1811. [CrossRef]

77. Yang, Y.L.; Goldrick, D.; Hong, J.S. Identification of the products and nucleotide sequences of two regulatory genes involved in the exogenous induction of phosphoglycerate transport in Salmonella typhimurium. J. Bacteriol. 1988, 170, 4299-4303. [CrossRef]

78. Pontes, M.H.; Groisman, E.A. Protein synthesis controls phosphate homeostasis. Genes Dev. 2018, 32, 79-92. [CrossRef]

79. Lucas, R.L.; Lee, C.A. Roles of hilC and hilD in regulation of hilA expression in Salmonella enterica serovar Typhimurium. J. Bacteriol. 2001, 183, 2733-2745. [CrossRef]

80. Miller, S.I.; Kukral, A.M.; Mekalanos, J.J. A two-component regulatory system (phoP phoQ) controls Salmonella typhimurium virulence. Proc. Natl. Acad. Sci. USA 1989, 86, 5054-5058. [CrossRef] 
81. Choi, E.; Groisman, E.A.; Shin, D. Activated by different signals, the PhoP/PhoQ two-component system differentially regulates metal uptake. J. Bacteriol. 2009, 191, 7174-7181. [CrossRef] [PubMed]

82. Shi, Y.; Cromie, M.J.; Hsu, F.F.; Turk, J.; Groisman, E.A. PhoP-regulated Salmonella resistance to the antimicrobial peptides magainin 2 and polymyxin B. Mol. Microbiol. 2004, 53, 229-241. [CrossRef] [PubMed]

83. Navarre, W.W.; Halsey, T.A.; Walthers, D.; Frye, J.; McClelland, M.; Potter, J.L.; Kenney, L.J.; Gunn, J.S.; Fang, F.C.; Libby, S.J. Co-regulation of Salmonella enterica genes required for virulence and resistance to antimicrobial peptides by SlyA and PhoP/PhoQ. Mol. Microbiol. 2005, 56, 492-508. [CrossRef] [PubMed]

84. van Velkinburgh, J.C.; Gunn, J.S. PhoP-PhoQ-regulated loci are required for enhanced bile resistance in Salmonella spp. Infect. Immun. 1999, 67, 1614-1622. [CrossRef] [PubMed]

85. Palmer, A.D.; Kim, K.; Slauch, J.M. PhoP-Mediated Repression of the SPI1 Type 3 Secretion System in Salmonella enterica Serovar Typhimurium. J. Bacteriol. 2019, 201. [CrossRef]

86. Gunn, J.S.; Ryan, S.S.; Van Velkinburgh, J.C.; Ernst, R.K.; Miller, S.I. Genetic and functional analysis of a PmrA-PmrB-regulated locus necessary for lipopolysaccharide modification, antimicrobial peptide resistance, and oral virulence of Salmonella enterica serovar typhimurium. Infect. Immun. 2000, 68, 6139-6146. [CrossRef]

87. Choi, J.; Groisman, E.A. The lipopolysaccharide modification regulator PmrA limits Salmonella virulence by repressing the type three-secretion system Spi/Ssa. Proc. Natl. Acad. Sci. USA 2013, 110, 9499-9504. [CrossRef]

88. Moreira, C.G.; Weinshenker, D.; Sperandio, V. QseC mediates Salmonella enterica serovar typhimurium virulence in vitro and in vivo. Infect. Immun. 2010, 78, 914-926. [CrossRef]

89. Merighi, M.; Septer, A.N.; Carroll-Portillo, A.; Bhatiya, A.; Porwollik, S.; McClelland, M.; Gunn, J.S. Genome-wide analysis of the PreA/PreB (QseB/QseC) regulon of Salmonella enterica serovar Typhimurium. BMC Microbiol. 2009, 9, 42. [CrossRef]

90. Mouslim, C.; Delgado, M.; Groisman, E.A. Activation of the RcsC/YojN/RcsB phosphorelay system attenuates Salmonella virulence. Mol. Microbiol. 2004, 54, 386-395. [CrossRef]

91. Farris, C.; Sanowar, S.; Bader, M.W.; Pfuetzner, R.; Miller, S.I. Antimicrobial peptides activate the Rcs regulon through the outer membrane lipoprotein RcsF. J. Bacteriol. 2010, 192, 4894-4903. [CrossRef] [PubMed]

92. Farizano, J.V.; Torres, M.A.; Pescaretti Mde, L.; Delgado, M.A. The RcsCDB regulatory system plays a crucial role in the protection of Salmonella enterica serovar Typhimurium against oxidative stress. Microbiology 2014, 160, 2190-2199. [CrossRef] [PubMed]

93. Cabeza, M.L.; Aguirre, A.; Soncini, F.C.; Vescovi, E.G. Induction of RpoS degradation by the two-component system regulator RstA in Salmonella enterica. J. Bacteriol. 2007, 189, 7335-7342. [CrossRef] [PubMed]

94. Jeon, J.; Kim, H.; Yun, J.; Ryu, S.; Groisman, E.A.; Shin, D. RstA-promoted expression of the ferrous iron transporter FeoB under iron-replete conditions enhances Fur activity in Salmonella enterica. J. Bacteriol. 2008, 190, 7326-7334. [CrossRef]

95. Tran, T.K.; Han, Q.Q.; Shi, Y.; Guo, L. A comparative proteomic analysis of Salmonella typhimurium under the regulation of the RstA/RstB and PhoP/PhoQ systems. Biochim. Biophys. Acta 2016, 1864, 1686-1695. [CrossRef]

96. Ahmer, B.M.; van Reeuwijk, J.; Watson, P.R.; Wallis, T.S.; Heffron, F. Salmonella SirA is a global regulator of genes mediating enteropathogenesis. Mol. Microbiol. 1999, 31, 971-982. [CrossRef]

97. Martinez, L.C.; Yakhnin, H.; Camacho, M.I.; Georgellis, D.; Babitzke, P.; Puente, J.L.; Bustamante, V.H. Integration of a complex regulatory cascade involving the SirA/BarA and Csr global regulatory systems that controls expression of the Salmonella SPI-1 and SPI-2 virulence regulons through HilD. Mol. Microbiol. 2011, 80, 1637-1656. [CrossRef]

98. Teplitski, M.; Goodier, R.I.; Ahmer, B.M. Pathways leading from BarA/SirA to motility and virulence gene expression in Salmonella. J. Bacteriol. 2003, 185, 7257-7265. [CrossRef]

99. Pickard, D.; Kingsley, R.A.; Hale, C.; Turner, K.; Sivaraman, K.; Wetter, M.; Langridge, G.; Dougan, G. A genomewide mutagenesis screen identifies multiple genes contributing to Vi capsular expression in Salmonella enterica serovar Typhi. J. Bacteriol. 2013, 195, 1320-1326. [CrossRef]

100. Johnston, C.; Pegues, D.A.; Hueck, C.J.; Lee, A.; Miller, S.I. Transcriptional activation of Salmonella typhimurium invasion genes by a member of the phosphorylated response-regulator superfamily. Mol. Microbiol. 1996, 22, 715-727. [CrossRef]

101. Ochman, H.; Soncini, F.C.; Solomon, F.; Groisman, E.A. Identification of a pathogenicity island required for Salmonella survival in host cells. Proc. Natl. Acad. Sci. USA 1996, 93, 7800-7804. [CrossRef] [PubMed] 
102. Brown, N.F.; Rogers, L.D.; Sanderson, K.L.; Gouw, J.W.; Hartland, E.L.; Foster, L.J. A horizontally acquired transcription factor coordinates Salmonella adaptations to host microenvironments. MBio 2014, 5, e01727-14. [CrossRef]

103. Perez-Morales, D.; Banda, M.M.; Chau, N.Y.E.; Salgado, H.; Martinez-Flores, I.; Ibarra, J.A.; Ilyas, B.; Coombes, B.K.; Bustamante, V.H. The transcriptional regulator SsrB is involved in a molecular switch controlling virulence lifestyles of Salmonella. PLoS Pathog. 2017, 13, e1006497. [CrossRef] [PubMed]

104. Widenhorn, K.A.; Somers, J.M.; Kay, W.W. Expression of the divergent tricarboxylate transport operon (tctI) of Salmonella typhimurium. J. Bacteriol. 1988, 170, 3223-3227. [CrossRef] [PubMed]

105. Baraquet, C.; Theraulaz, L.; Guiral, M.; Lafitte, D.; Mejean, V.; Jourlin-Castelli, C. TorT, a member of a new periplasmic binding protein family, triggers induction of the Tor respiratory system upon trimethylamine N-oxide electron-acceptor binding in Escherichia coli. J. Biol. Chem. 2006, 281, 38189-38199. [CrossRef] [PubMed]

106. Hensel, M.; Hinsley, A.P.; Nikolaus, T.; Sawers, G.; Berks, B.C. The genetic basis of tetrathionate respiration in Salmonella typhimurium. Mol. Microbiol. 1999, 32, 275-287. [CrossRef]

107. Wong, V.K.; Pickard, D.J.; Barquist, L.; Sivaraman, K.; Page, A.J.; Hart, P.J.; Arends, M.J.; Holt, K.E.; Kane, L.; Mottram, L.F.; et al. Characterization of the yehUT two-component regulatory system of Salmonella enterica Serovar Typhi and Typhimurium. PLoS ONE 2013, 8, e84567. [CrossRef]

108. Kier, L.D.; Weppelman, R.M.; Ames, B.N. Regulation of nonspecific acid phosphatase in Salmonella: phoN and phoP genes. J. Bacteriol. 1979, 138, 155-161. [CrossRef]

109. Miller, S.I.; Mekalanos, J.J. Constitutive expression of the phoP regulon attenuates Salmonella virulence and survival within macrophages. J. Bacteriol. 1990, 172, 2485-2490. [CrossRef]

110. Pullinger, G.D.; van Diemen, P.M.; Dziva, F.; Stevens, M.P. Role of two-component sensory systems of Salmonella enterica serovar Dublin in the pathogenesis of systemic salmonellosis in cattle. Microbiology 2010, 156, 3108-3122. [CrossRef]

111. Karlinsey, J.E.; Stepien, T.A.; Mayho, M.; Singletary, L.A.; Bingham-Ramos, L.K.; Brehm, M.A.; Greiner, D.L.; Shultz, L.D.; Gallagher, L.A.; Bawn, M.; et al. Genome-wide Analysis of Salmonella enterica serovar Typhi in Humanized Mice Reveals Key Virulence Features. Cell Host Microbe 2019, 26, 426-434 e426. [CrossRef] [PubMed]

112. Winter, S.E.; Thiennimitr, P.; Winter, M.G.; Butler, B.P.; Huseby, D.L.; Crawford, R.W.; Russell, J.M.; Bevins, C.L.; Adams, L.G.; Tsolis, R.M.; et al. Gut inflammation provides a respiratory electron acceptor for Salmonella. Nature 2010, 467, 426-429. [CrossRef]

113. Jourlin, C.; Ansaldi, M.; Mejean, V. Transphosphorylation of the TorR response regulator requires the three phosphorylation sites of the TorS unorthodox sensor in Escherichia coli. J. Mol. Biol. 1997, 267, 770-777. [CrossRef] [PubMed]

114. Mejean, V.; Iobbi-Nivol, C.; Lepelletier, M.; Giordano, G.; Chippaux, M.; Pascal, M.C. TMAO anaerobic respiration in Escherichia coli: Involvement of the tor operon. Mol. Microbiol. 1994, 11, 1169-1179. [CrossRef] [PubMed]

115. Gon, S.; Giudici-Orticoni, M.T.; Mejean, V.; Iobbi-Nivol, C. Electron transfer and binding of the c-type cytochrome TorC to the trimethylamine N-oxide reductase in Escherichia coli. J. Biol. Chem. 2001, 276, 11545-11551. [CrossRef]

116. McCrindle, S.L.; Kappler, U.; McEwan, A.G. Microbial dimethylsulfoxide and trimethylamine-N-oxide respiration. Adv. Microb. Physiol. 2005, 50, 147-198. [CrossRef]

117. Teplitski, M.; Goodier, R.I.; Ahmer, B.M. Catabolite repression of the SirA regulatory cascade in Salmonella enterica. Int. J. Med. Microbiol. 2006, 296, 449-466. [CrossRef]

118. Kossack, R.E.; Guerrant, R.L.; Densen, P.; Schadelin, J.; Mandell, G.L. Diminished neutrophil oxidative metabolism after phagocytosis of virulent Salmonella typhi. Infect. Immun. 1981, 31, 674-678. [CrossRef]

119. Perkins, T.T.; Kingsley, R.A.; Fookes, M.C.; Gardner, P.P.; James, K.D.; Yu, L.; Assefa, S.A.; He, M.; Croucher, N.J.; Pickard, D.J.; et al. A strand-specific RNA-Seq analysis of the transcriptome of the typhoid bacillus Salmonella typhi. PLoS Genet. 2009, 5, e1000569. [CrossRef]

(C) 2020 by the authors. Licensee MDPI, Basel, Switzerland. This article is an open access article distributed under the terms and conditions of the Creative Commons Attribution (CC BY) license (http://creativecommons.org/licenses/by/4.0/). 